\title{
VILLAGE HEALTH WORKERS: FIRST LINE OF CONTACT IN THE REPUBLIC OF CISKEI
}

\author{
CECIL RAUTENBACH
}

\section{OPSOMMING}

\begin{abstract}
Dorpsgesondheidswerkers word met welslae in die Republiek van Ciskei as eerste punt van kontak vir gesondheidsdienste gebruik. Eers was 'n addisionele 3-maande kursus vir ingeskrewe verpleegkundiges, wat pas hulle kurus voltooi het, aangebied. Nou word persone uit die gemeenskappe geneem en, volgens die regulasies van die SARV, as verpleegassistente opgelei. Na die opleiding keer hulle terug na hulle dorpe om gesondheidsprobleme te identifiseer asook om gesondheidsvoorligting, verwysings, en opvolgwerk te doen. Daar word ook van hulle verwag om 'n plaaslike gesondheidskomitee daar te stel.

Hierdie gesondheidswerkers word gereeld opgevolg en spesiale maandelikse opdragte, soos byvoorbeeld om algemene veltoestande op te spoor of om alle voorskoolse kinders in hulle dorp te weeg, is baie geslaagd. Aanvanklike navorsing toon dat hierdie persone 'n effektiewe bydrae tot die voorkoming en vroeë opsporing van siekte lewer.
\end{abstract}

\section{INTRODUCTION}

The health care of the majority of the inhabitants of South Africa's rural areas has given cause for concern for a long time. There are a number of suggested reasons for this.

First of all, the burden of illhealth seems to be heaviest in the rural areas. There are few statistics that show this accurately but two recent surveys of infant mortality in rural areas showed rates as high as 198 per 1000 (Shuenyane, 1984) and 282 per 1000 (Knutsen and Bowne, 1977). This may be compared with infant mortalities ranging from 10 to 60 per 1000 (Sutter, 1984) in the urban population. The high mortality rates at an early age in the rural areas are mainly related to undernutrition and infectious diseases.

Secondly, the rural areas have fewer doctors and their number seems to be decreasing (the ratio of doctors to population in urban areas in 1975 was 1:875 compared with $1: 12700$ in rural areas. By 1981 this ratio had changed to

Professor Cecil Rautenbach, Head: Department of Health Sciences, University of Fort Hare.

BCur (I et A) (UPE); MCur (Nursing Ed) (UPE); DCur (UPE). RMN; CHN; NEd.; N Admin; Nat. Dip. Health Ed.
1:1200 for the urban areas and 1:17500 for rural areas. (Dept of Health Statistics). Rural areas also have fewer hospital beds for their population and the overall expenditure on health services in the rural areas is very limited.

\section{THE HEALTH MANPOWER PYRAMID}

At the present time there is a very definite medical pyramid that exists in the recognised First World. This pyramid is rigidly adheared to and has rigidly delineated levels that places the community at the bottom of the stack (Paper, 1984) (See figure 1).

Because there are enough medical practitioners to give the necessary care and to allow for rigid inter- sections between medical team members the above pyramid is accepted.

In areas where there are not enough medical practitioners the pyramid cannot succeed. In this case the only way that successful medical care can be given is by means of team work with the pyramid still in use but where the people come first. (Paper, 1984) (See figure 2).

The result of this is that the emphasis is placed on the community and because the community is involved the shift is away from curative to preventive medicine.

The above comment raises a number of problems and these can best be summarised as in outline 1 (Paper, 1984).

\section{Figure 1 THE TYPICAL MEDICAL PYRAMID}

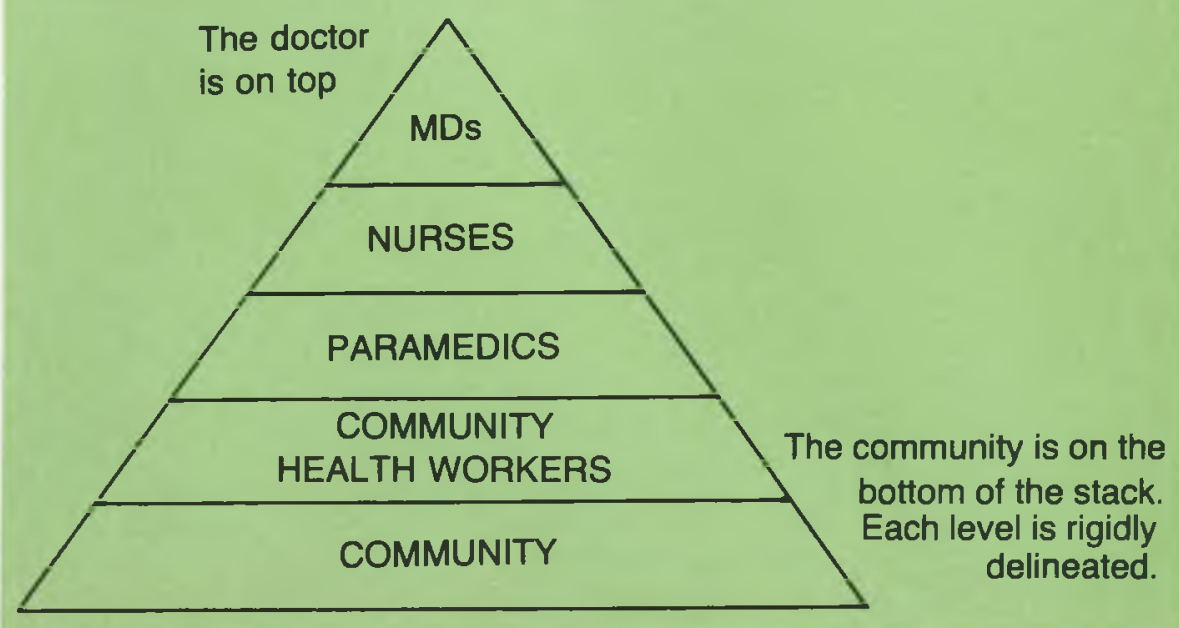


VILLAGE HEALTH WORKERS IN THE REPUBLIC OF CISKEI

\section{Training}

Village health workers were used successfully in many parts of the world. In 1980 the first sixteen enrolled nurses were given a special course of three month's duration from the time they finished their examinations until they received their results. They were trained to be village health workers.
Figure 2 THE PYRAMID AS IT SHOULD BE

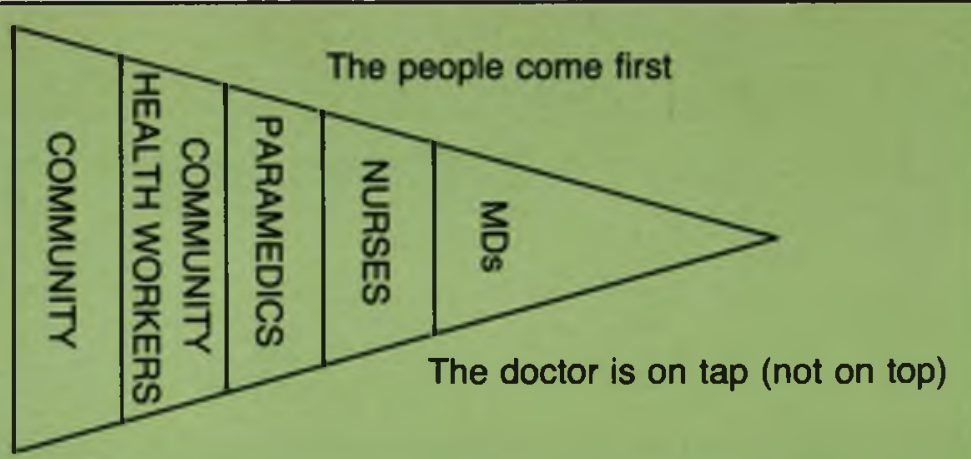

The community health worker assumes the lead role in the health team.

OUTLINE 1 We say prevention is more important than cure - but where should prevention begin?

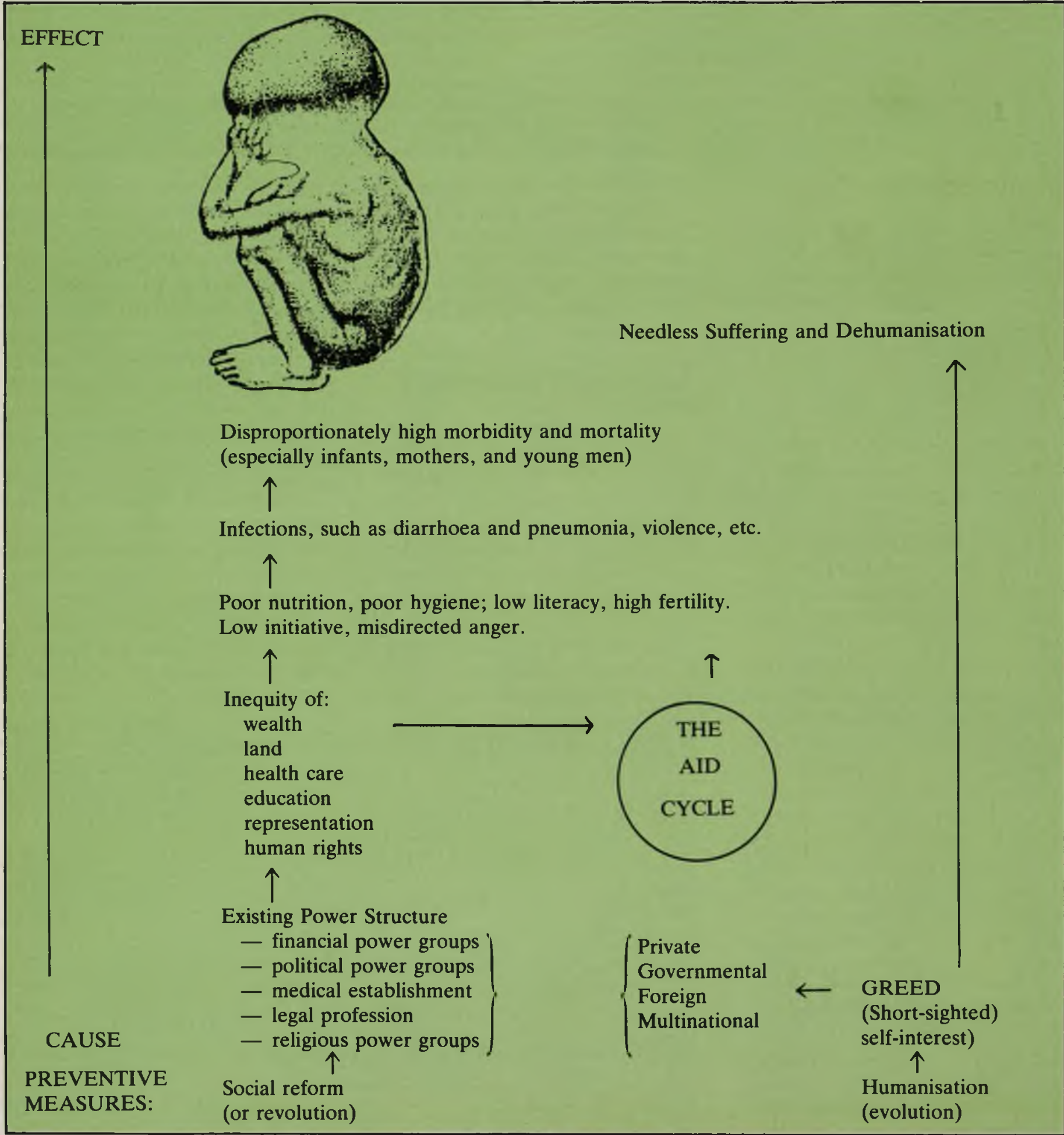


The course content is given below.

- Child welfare with special emphasis on:

- supervision of growth

- recognising the at risk child

- organisation of a baby-clinic

- treatment of: common skin diseases

diarrhoea

worm infestation.

- Nutrition with special emphasis on:

- promotion of breastfeeding

- introduction of solids

- nutrition education

- Ante-natal and post-natal care with special emphasis on the follow-up of home deliveries and the detection of neonatal complications.

- Family planning motivator's course.

- Environmental hygiene, sanitation, safe water supply.

- Tuberculosis control.

\section{- Home visiting}

Lectures were also given on the following topics: dental hygiene, psychiatry, follow-up of chronic medical cases, people in need of a social worker, dry land gardening.

During the course the emphasis was not so much on theoretical knowledge but attaining practical skills. After completion of the course, ten of the sixteen candidates were stationed in nine different villages in the Peddie District. The villages were chosen in conjunction with the local Member of Parliament and represented all the tribal authorities. The community provided accommodation for the nurse.

\section{Functions}

The nurse concentrated at first on the functions given below.

\section{Systematic home visits in their village}

- Identification of health problems and
- giving appropriate health education

- doing follow-up visits to see progress

- referring to specialist services (such as the psychiatric nurse, social worker)

- Motivating people to make use of existing medical services, including the child welfare clinic, antenatal clinic, family planning.

\section{Attending clinics}

Attending local child welfare and ante-natal clinics weekly in order to identify problem cases that need home visits, for example malnourished children and visits to antenatal cases. These nurses were visited weekly by a mobile clinic which served as a referral centre.

\section{Following up special cases}

- Malnourished children, that is: below 3rd centile or no weight gain for three months or more.

- Post-natal care of home deliveries or deliveries discharged from hospital or clinic.

- Tuberculosis contacts or defaulters.

- Chronic cases, such as patients with epilepsy, diabetes and hypertension.

- Psychiatric cases.

- Family planning clients.

\section{Health Committee}

To establish a local Health Committee and arrange regular meetings.

Special emphasis was placed on the nurses' role as nutrition educators, that is: the promotion of breastfeeding and balanced diets as well as the follow-up of malnourished children. Another important function was the home management of diarrhoea and to make oral rehydration readily available.

\section{Follow-up}

A monthly feed-back meeting at the hospital kept contact with these nurses. After several months the following facts became clear:

- the attendance at the mobile clinic in the villages where these nurses worked rose sharply, especially for the under-five clinic
- these nurses were very good at recognising pathetic social cases in need of urgent attention and these could be referred to the social worker

- the importance of close supervision of the work of these nurses became very clear. A registered nurse was appointed as supervisor and to organise future courses. Lack of transport made proper supervision difficult

- people often asked the nurses for medicines. This emphasised again the fact that preventive and promotive medicine without curative medicines is not very well accepted. As a result of this, the nurses were allowed to keep a limited amount of medicines to be issued as one dose only. These included mainly simple dermatological preparations, pain tablets and oral rehydration powder. The nurses were also allowed to do daily dressings of surgical wounds mainly on patients referred from the hospital

- after the nurses finished the first round of home visits, they became discouraged by not seeing any immediate results. On follow-up home visits they still did not see any results. This affected their motivation and some lost interest.

After the initial course a number of new procedures were introduced to make the nurses' work more interesting.

- A home visit card was introduced. This card is completed for every household and is filed by each nurse. Notes on followup visits are attached to these cards. This also helps supervisors to get an idea of the number of households and the number of inhabitants of each village.

- A register for malnourished children was introduced. Weekly weights of malnourished children are plotted on a graph and the nurses are encouraged to visit these children frequently, even daily if necessary. This became a major task as some nurses have up to twenty malnourished children to visit. 
- An attendance register for patients suffering from chronic medical conditions was introduced. Non-attenders could then be visited at home.

- The nurses were allowed to treat tuberculosis patients as outpatients on a daily basis. Patients on the 120-day regime (including Rifadin) were carefully selected at hospital level to make sure that they stay within easy walking distance from the nurse. The patients take their treatment daily from the nurse and she is in a position to trace the patients immediately if they do not attend. She can also trace contacts at the patient's home.

- At each monthly meeting a health topic was decided on. The nurses then talk to the Health Committee members who in turn spread the information to the community. This was introduced to keep the members of the Health Committees motivated.

- A week-long refresher course for the nurses was organised.

\section{Second course}

In June 1981 the second course started with sixteen candidates. Ten candidates passed their examinations and these were then all attached to permanent clinics for two reasons:

- it became apparent that these nurses could be used in communities around permanent clinics as well

- supervision is easier, especially where there is no mobile clinic to visit them regularly.

At this stage a major problem arose - it related to the selection of candidates. Up to this point only enrolled nurses who had completed their training had been used. It soon became apparent that some candidates were not well motivated for their work. Attending the course and being employed in this way meant continuous employment for some of the nurses. Previously they often had to wait for a permanent post for a long time after qualifying.

\section{Nursing Assistants}

After consideration of the problems the whole project was rethought and the following changes were made:

- in future enrolled nursing assistants instead of enrolled nurses would be trained as village health workers

- the candidates would be selected by their own community

- the minimum educational requirements would be Std 5

- they would be trained for six months, enrol as nursing assistants with the Nursing Council and then return to their own villages.

The six-months' training was divided into two parts, a two-months theoretical and a two-months practical part. The theoretical part corresponded with the course given to the enrolled nurses. The new candidates, however, had no nursing background, and also had low educational qualifications. The course had to comply with the requirements laid down for enrolled nursing assistants by the Nursing Council. Therefore lectures on nursing ethics, basic anatomy and physiology as well as first aid were included.

During the practical part trainees were divided into small groups and spent two-week periods in the following departments:

- maternity

- paediatric outpatients

- family planning/psychiatric clinic

- nutrition rehabilitation centre

- mobile clinic

- tuberculosis treatment

- permanent clinic

- stay with a village health worker.

On completing their training these trainees were enrolled as nursing assistants and then returned to their villages as village health workers.

At present the use of the village health workers is continuing. Their role and function is being monitored closely.

\section{Assignments}

Meetings are held monthly on the day that the doctor visits a particular clinic. Each worker then reports his or her activities during the past month, a lecture and/or demonstration by the doctor follows and finally a practical assignment for the coming month is set.

Lectures have included:

- immunisation

- breastfeeding

- weaning and principles of nutrition

- use of Child Health Card, including plotting of weight on the graph

- common skin conditions

- spread of infectious diseases

- tuberculosis

- gastro-enteritis

- oral rehydration therapy

- prevention and management of burns

- high blood pressure

- epilepsy

- cholera.

Some of the assignments have been very effective. The following are a few examples.

Checking immunisation status of all babies and pre-school children and referral to clinics where applicable. In one area this led to the referral in one month of 305 children who required some immunisation but were not attending clinic and the detection of five new cases of active tuberculosis. Although a new assignment is set each month, workers are expected to apply their accumulated knowledge at all times and in the case of immunisation surveillance, this has been especially useful in ensuring that children are being protected against tuberculosis and measles.

Weighing of pre-school children in each village. Many children are already enjoying nutritional surveillance and advice if they stray from the Road to Health chart. Workers are becoming proficient in the use of this chart and are able to interpret it intelligently.

Detection of common skin diseases. During one month, workers carried out a campaign to detect common skin diseases such as scabies, impetigo, ringworms and 
nappy rash. They called meetings in their villages and discussed the causes and prevention of these diseases. Hundreds of children were referred to the clinics for management.

Workers are expected to call regular meetings to discuss the topic of the month. Discussions and ideas are invited from the audience. The meetings are often held in conjunction with the headmen's meetings.

The whole scheme appears to be gaining the support, co-operation and respect of the community and headmen, in a most gratifying way.

An overwhelming number of patients with chronic diseases and handicaps have been discovered and referred for whatever treatment or help is available. Many are serious socio-medical problems where a grant, which is applied for, constitutes the best therapy.

The cholera threat demonstrated how effective Village Health Workers can be. They called meetings in all their villages, demonstrated the use of suitable chemicals for water purification (household bleach) and how to build pit latrines. In one area more than one hundred latrines have been dug.

When people complained that they did not have materials and money to erect enclosures for their latrines, one village health worker suggested that they use the soil they had dug out to make mud bricks and use these for building the walls of the lavatories. They have also encouraged people, for their own good, to buy their own bleach and not always to depend on the clinics or authorities. It is clear that they promote self-reliance very effectively.

In addition to their more medical activities, vegetable gardening has also been undertaken. Pig and poultry farms are under consideration.

All this has been achieved with only a few hours of lectures and assignments.

\section{Conclusion}

Dr $\mathrm{T}$ Thomas in considering the work carried out by the village health workers made the following statement:

$I$ would like to submit that it is only necessary to train sufficient health workers to ensure childhood immunisation, promote breast-feeding monitor nutrition and the Road to Health Card, recognise and act upon the causes and signs of malnutrition, gastro-enteritis, tuberculosis and measles, and to understand and propagate a hygienic life style for them to make a remarkable impact on the health of their villages.

All this is entirely feasible and well within the ability of interested and well-chosen village health workers and they are in fact ideally placed to carry it out. There can be no pretence that the present health service is reaching all the people it is meant to serve. Nurses are necessarily clinic-bound because of the shortage of staff and are overburdened with curative and administrative work.
They have no transport so that any outgoing work is necessarily minimal. These considerations apply with special emphasis on the rural areas where staff/patient ratio is particularly unfavourable and where clinics serve huge areas with scattered communities. (Thomas 1984).

The development of a network of well trained village health workers provides an excellent first line of defence in health care. At the present moment the biggest stumbling block is the question of remuneration of the village health workers. This question is receiving attention and a number of methods are being considered but as yet no answer has been found.

Ongoing research is being carried out on the effectiveness of the village health workers. Preliminary research results have indicated that these people are an effective first line of health defence and their task, as well as effectiveness, will be closely monitored.

\section{REFERENCES}

Department of Health, Republic of Ciskei. (1984) Statistics, 1984.

Knutsen, V.K ; Bowne, D.E. , (1977) The reproductive efficiency of the Xhosa. South African Medical Journal $51,392$.

Shuenyane, E. et al (1984) A Demographic and socio-econ omic profile of a rural Black South African community South African Medical Joumal 57, 539.

Sutter, E.E. (1984) Village health workers. Unpublished paper delivered at a Congress on Village Health Work ers. Cecilia Makiwane Hospital. September 1984.

Thomas, T. (1984) Village health workers at Newlands and Chalumna. Unpublished paper delivered at a Congress on Village Health Workers. Cecilia Makiwane Hospital. September 1984.

Village health worker - lechey or liberator. (1984) Unpublished paper delivered at a Congress on Village Heaith Workers. Cecilia Makiwane Hospital. September 1984

\section{(Vervolg vanaf $p$ 19)}

speel. Hierdie tipe opleiding kan dus met vrug in die programme van studentverpleegkundiges ingesluit word.

Dit word verder weer eens duidelik hoe belangrik dit is om die effektiwiteit van leergeleenthede te evalueer. Baie dosent- en studente-ure gaan verlore in oneffektiewe leergeleenthede.

Schlofeldt en Methven se empatie-skaal tel uit dertig. Dit is opmerklik dat, na twee semesters van redelik intensiewe opleiding op hierdie gebied, die groep se gemiddeld steeds maar dertien (13) is. Dit is nog baie na aan die onterapeutiese punt wat op onder 10 punte gestel word. Dit is belangrik om nie die doelwitte ten opsigte van interpersoonlike vaardighede vir studentverpleegkundiges te hoog te stel nie. Dit sou onrealisties wees as die ontwikkelingstadium van die student self en die ingewikkeldheid van die taak in aanmerking geneem word.

\section{BIBLIOGRAFIE}

Burgess, A.C.; Lazare, A. (1973) Psychiatric nursing in the hospital and the community. Englewood Cliffs. Prentice Hall.

Egan, G. (1970) Encounter: group process for interpersonal growth. Belmont. Brooks/Cole Publ.

Egan G. (1975) The skilled helper: a model for systematic helping and interpersonal relaning. Monterey. Brooks Cole Publ.

Guilford J.P. (1956) Fundamental statistics in psychology and education. New York. McGraw-Hill. 4th Ed.

Infante, M.S. (1975). The clinical laboratory in nursing education. New York. John Wiley.

Manaser, J.C.; Werner, A.M. (1964) Instruments for study of nurse-parient interaction. New York. Macmillan.

Methven, D; Schlotfeldt, R.M. (1962) The Social interaction inventory. Nursing Research. 2(2): 83 - 88. Spring 1962.

Simmons, J.A. (1976) The nurse-client relationship in mental health nursing. Philadelphia. W.B. Saunders. 2nd Ed. 